\title{
VALIDITY AND THE SCHOLASTIC APTITUDE TEST; RECENT SELECTIONS FROM ERIC
}

\author{
Submittedby \\ Nancy R Preston
}

\section{Journal Articles}

Baker, Harold. (1992, Jan.). Soundoff: The SAT Should Be Revised. Mathematics Teacher, 85(1), 14-15. (Available UMI).

Suggested are ways to improve the SAT and its face validity. Suggestions include greater emphasis on morerealistic problems, inclusion of realistic percent problems, modification of the multiple-choice format, and the use of the National Council of Mathematics "Curriculum and Evaluation Standards" as a guide to construct the test.

Braswell, James S. (1992, Jan.). Changes in the SAT in 1994. Mathematics Teacher, 85(1), 16-21. (Available UMI).

Described are important changes that will be introduced in the mathematics sections of the new Scholastic Aptitude Test (SAT). The three main changes are (1) permission to use calculators; (2) inclusion of open-ended questions; and (3) content revisions consistent with the National Council of Teachers of Mathematics "Curriculum and Evaluation Standards."

Jacobs, Walter R., Jr. (1991, Spring). The Traditional Role of the SAT in the 1990s. Journal of College Admission, 131, 21-26.

Draws on 20 years of experience as College Board staff member to discuss the traditional role of the Scholastic Aptitude Test (SAT), test bias, a new and emerging role for the SAT, and the SAT's interaction with other testing methods.

Kubota, Mel, \& Connell, Anne. (1992, Winter). On Diversity and the SAT. College BoardReview, 162, 6-1. (Available UMI).

The processes used in developing the Scholastic Aptitude Test (SAT) to eliminate cultural bias while still measuring skills related to academic success are described, including test item writing, pretesting, and validation. Test items from 1908, 1927, 1947, and 1980 tests illustrate the evolution of the examinations.
Mandula, Barbara. (1990, Jan.-Feb.). Is the SAT Unfair to Women? AWIS Newsletter, 19(1), 8-10. (Journal availability: AWIS National Office, 2401 Virginia Ave., N.W., Suite 303, Washington, DC 20037.)

Reviewed is the research of Dr. Phyllis Rosser and the comments made by several speakers at a hearing on gender bias in testing held in October 1989. Discussed are historical perspectives, the gender gap in testing, and possible explanations for this gap. Sample test items are provided.

The New SAT: Debating Its Implications. (1991, Winter). College Board Review, 15, 22-27. (Available UMI).

A group of eight educators and one law student discusses the most recent changes in the Scholastic Aptitude Test content and format, which will include a reasoning test and a battery of subject tests. Comments focus on general reactions, specific additions and deletions, test bias, implications for admissions, and coaching.

Stricker, Lawrence J. (1991, Summer). Current Validityof 1975 and 1985 SATs: Implications for Validity Trends since the Mid-1970s. Journal of Educational Measurement, 28(2), 93-98.

To study whether different forms of the Scholastic Aptitude Test (SAT) used since the mid-1970s varied in their correlations with academic performance criteria, 1975 and 1985 forms were administered to 1,554 and 1,753 high school juniors, respectively. The 1975 form did not have greater validity than the 1985 form.

Wainer, Howard, \& Steinberg, Linda S. (1992, Fall). Sex Differences in Performance on the Mathematics Section of the Scholastic Aptitude Test: A Bidirectional Validity Study. Harvard Educational Review, 62(3), 323-36. (Available UMI).

Matching almost 47,000 men and women on type of math course taken and grade received, women scored about 33 points lower on the Scholastic Aptitude Test-Mathematics than men who had taken the same course and received the same grade. Sex differences call into question the validity of the SAT as a predictor of college math performance. 


\section{ERIC Documents}

Jenkins, Neil J. (1992, July). The Scholastic Aptitude Test as a Predictor of Academic Success: A Literature Review. 11pp. (Available from EDRS as ED 354243 ; microfiche or paper copy.)

Although used by a large number of American colleges, the SAT and similar tests are not widely used for either evaluation of potential success or admissions screening by postsecondary institutions in Canada. This review of nine studies considers the predictive validity of the SAT for Canadian postsecondary institutions and confirms that at best the SAT can be used as a supplement to high school GPA.

McManus, Barbara Luger. (1992). The Revised SAT's and the ACT's-Are They Really Different? 12pp. (Available from EDRS as ED 352 368; microfiche or paper copy.)

This paper discusses whether or not revisions of the Scholastic Aptitude Test (SAT) and the American College Test (ACT) have created such significant differences between the two tests that a student could conceivably score significantly higher on one than the other. A review of the characteristics of both tests suggests that a student who is a divergent thinker, an underachiever, a member of a minority group, from a mediocre highschool, or good in mathematics could do better on the SAT. A student with a good educational background, good grades in high school, or a weakness in mathematics might choose to take the ACT or both tests.

Valley, John R. (1992). The SAT: Four Major Modifications of the 1970-85 Era. New York, NY: College Entrance Examination Board. 35pp. ED 350 335; 35pp. (Available from EDRS as ED 350 335; microf iche copy only. Also available from College Board Publications, Box 886, New York, NY 10101-0886, \$12.)

This report describes major modifications made to the SAT from 1970 to 1985 caused by: (1) the addition of the Test of Standard Written English (TSWE) to the College Board's Admissions Testing Program (ATP); (2) the passage of test disclosure legislation; (3) the institution of test sensitivity reviews; and (4) the use of item response theory equating in SAT scores. The relationship of these modifications to the SAT's content, format, development procedures, psychometric characteristics, and statistical procedures are discussed.

\section{How to Obtain Materials Cited in this Bibliography:}

Journal articles citations are from Current Index to Journals in Education. The articles may be obtained from a college, university, or large public library, borrowed through interlibrary loan, or, if so indicated, ordered from: UMI Article Clearinghouse, 300 N. Zeeb Road, Ann Arbor, MI 48106. Phone: 1- 800-5210600.

ERIC Documents are announced in Resources in Education. They can be read in full text at any library holding an ERIC microfiche collection. They can also be ordered, in paper or microfiche copy, from the ERIC Document Reproduction Service (EDRS), 7420 Fullerton Road, Suite 110, Springfield, VA 22153-2852. Phone: 1-800-443-ERIC or 703-440-1400. Call for prices and delivery options.

Nancy R. Preston is Assistant Director, ERIC Clearinghouse on Information \& Technology, 4-194 Center for Science and Technology, Syracuse University, Syracuse, NY 13244-4100; (315) 443-3640;800464-9107; npreston@ericir.syr.edu. 